\title{
NOTES
}

\section{CASES MOOT ON APPEAL: A LIMIT ON THE JUDICIAL POWER}

Since the judiciary is an equal branch in the federal and state governmental systems, determination of the extent of judicial power becomes a crucial problem in the effort to maintain the integrity and independence of each of the branches of government. In the United States the courts themselves have largely determined the limits of judicial power through interpretation of the constitutions and through other self-imposed limitations. ${ }^{1}$ While the exact scope of the power and its limits and application have never been set forth precisely, a large body of law has grown up to which every such question is referred. ${ }^{2}$

Under the Federal Constitution, the courts of the United States can render decisions only in "cases" and "controversies." 3 However, these terms inherently are capable of many varying interpretations and have never been defined authoritatively. 4 Hence, any restriction of judicial power created by construction of such terms may properly be termed self-imposed. In determining what acts fall outside the scope of the judicial function, courts have established the rule that they have no power to decide moot cases. ${ }^{5}$ Since a court is deprived of jurisdiction when a case becomes moot,

1. Harris, The Judictal Power of the United States 1-2 (1940). See also, Vanderbilt, The Doctrine of the Separatton of Powers and Its Present-Day SignIFICANCE (1953); Note, Judicial Self-Restraint in New Jersey, 8 RutGers L. REv. 501 (1954).

These restrictions on the judicial power have been opposed, for varying reasons, in Albertsworth, Advisory Functions in Federal Supreme Court, 23 GEo. L.J. 643 (1935); Arnold, Trial by Combat and the New Deal, 47 HARv. L. REv. 913 (1934); HARrIs, op. cit. supra; Pound, Jurisprudence: Science or Superstition, 18 A.B.A.J. 312 (1932); VANDERBILT, op. cit. supra.

2. HaRRIS, op. cit. supra note 1 , at 7-9.

3. U.S. Const. Art. III, \$2; Muskrat v. United States, 219 U.S. 346, 356 (1911) ; Stearns v. Wood, 236 U.S. 75, 78 (1915): "The province of courts is to decide real controversies, not to discuss abstract propositions."

4. Mills v. Green, 159 U.S. 651 (1895). "Judicial power can be exercised only as to matters that were the traditional concern of the courts at Westminster, and only if they arise in ways that to the expert feel of lawyers constitute 'Cases' or 'Controversies.' Even as to questions that were the staple of judicial business, it is not for the courts to pass upon them unless they are indispensably involved in a conventional litigation. . ." Frankfurter, J., concurring in Youngstown Sheet \& Tube Co. v. Sawyer, 343 U.S. 579, 594 (1952). (italics added). The terms were probably not intended to set forth jurisdictional limits rigidly.

5. Michael, The Elements of Legal Controversy 94-117 (1948); Mills v. Green, 159 U.S. 651 (1895) ; Southern Pac. Term. Co. v. ICC, 219 U.S. 498, 514 (1911); Tregea v. Modesto Irrig. Dist., 164 U.S. 179 (1896); In re Workmen's Comp. Fund, 224 N.Y. 13, 119 N.E. 1027 (1918). However, the state courts have established a "public interest" exception to this general rule. See text at notes 105-36 infra. 
the fact of mootness can be raised at any time during the judicial proceeding and, once proved, will prevent decision of the case on the merits. ${ }^{6}$

The most important and basic reason for judicial denial of the power to decide moot cases is one which lies at the very heart of common-law jurisprudence. Our basic legal philosophy is premised on the theory that the best way to achieve a wise resolution of disputed legal matters is to allow each party his day in court to present his views, with opportunity to challenge and rebut those of his opponent. This adversary system depends upon self-interest as the motive best suited to bring all pertinent facts, policies and legal issues before the court. ${ }^{7}$ When one party to an action has nothing to gain from a decision in his favor, many of the advantages of the adversary system are likely to be lost, since a disinterested person probably will not exert the same effort to bring all considerations before the court as one about to be affected adversely by an unfavorable decision. Familiar with adversary proceedings and often quite dependent upon counsel for facts, argument and authority, courts are more likely to be led into error in a non-adversary situation, especially one which in form resembles customary proceedings. ${ }^{8}$ When such error may be used as the basis for future decisions, the harm becomes a serious one and the requirement of adverse interests at the bar assumes great importance. In addition, parties who may never get into court may rely upon the decision and change their positions to their detriment.

6. United States v. Felin \& Co., 334 U.S. 624, 640 (1948); Swift \& Co. v. Hocking Valley Ry., 243 U.S. 281 (1917); Cover v. Schwartz, 133 F.2d 541, 546 (2d Cir. 1942). In the Supreme Court, facts showing mootness may be brought out by judicial notice, by an amicus curiae, or by either party in a brief, motion to dismiss, brief opposing grant of certiorari, memorandum, oral argument, or subsequent memorandum. Stern \& Grossman, Supreare Court Practice $338-49$ (1950).

7. See Bischoff, Status to Challenge Constitutionality in Supreare CourT AND Suprense LAw 26 et seq. (Cahn ed. 1954); Freund, ON UNDERstanding tHe SUPREME COURT 79-80, 84-88 (1951).

8. This theory can be applied on only a very general basis. In given instances, a decision in a non-adversary situation may be of higher quality than one in an adversary situation. It is difficult to comprehend why one should feel assured of the soundness of an opinion as to an important issue in cases involving small amounts of money, whereas it is considered too dangerous to decide the same issue in a moot suit. But the need for convenience requires that $a$ line be drawn and it has been deemed best to draw that line where all self-interest of a party is lacking. However, the proposition that an opinion in a moot case would have to be disregarded because of the dangers surrounding its formation should not be accepted as valid in every instance. Many of the opinions in moot cases decided under the public interest exception, see text following note 105 infra, appear to be thoroughly researched and well-reasoned. See, e.g., Huffman v. Alexander, 197 Ore. 283, 251 P.2d 87, rehearing devied, 197 Ore. 331, 253 P.2đ 289 (1953) (discussing habeas corpus), which was described in a concurring opinion as "a splendid and valuable contribution to the law. . ." Id. at 351, 253 P.2d at 298 .

In addition, the courts do realize that dangers of an unwise decision exist even where there is an actual controversy between the parties. An example of this is the United States Supreme Court's reluctance to decide constitutional issues except where absolutely necessary to the decision of the case. For a list of these restrictions on deciding constitutional questions, see the concurring opinion of Justice Brandeis in Ashwander v. TVA, 297 U.S. 288, 345-48 (1936). The mootness doctrine is a convenient one for implementing the characteristic avoidance of constitutional questions. See St. Pierre v. United States, 319 U.S. 41 (1943). 
Moot cases have often been equated to advisory opinions because of the likelihood in each that all arguments will not be fully presented. ${ }^{9}$ Principally because of this deficiency, advisory opinions have never been given widespread acceptance in this country. ${ }^{10}$ It is conceded that advisory opinions may have great utility, especially during periods in which much experimental legislation is being enacted, in alleviating the uncertainty, doubt and confusion which abound when the constitutionality of such statutes is undecided.11 However, there is a danger that advisory opinions will create undesirable precedents because the "impact of actuality" is wanting, ${ }^{12}$ and because generally only one side is argued before the court. ${ }^{13}$ When the constitutionality of a statute is in issue, it is thought that the court should be faced with a record of the statute's actual operation, compiled in an adversary proceeding with all the safeguards of rules of evidence and crossexamination, rather than with the bare words of the statute without the gloss of administrative or executive interpretation and enforcement. ${ }^{14}$ However, moot cases do not present all the dangers of advisory opinions. The "impact of actuality" may well be lacking if the court knows that its decree cannot affect the rights of the parties. But there is a record to which the court may look for facts; there is probably as much experience under the statute as might be had in a case which is not moot; and there are advocates before the court who are prepared to argue the issues. ${ }^{15} \mathrm{Al}-$ though some comparison may be made between moot cases and advisory opinions, the desirability of rendering decision in moot cases cannot be resolved merely by such a comparison.

Generally speaking, a case is moot when a party has no legal interest in the outcome. ${ }^{16}$ Such lack of interest may result from various causes.

9. See, e.g., Donato v. Board of Barber Examiners, 56 Cal. App.2d 916, 133 P.2d 490 (1943).

10. Seven states render such opinions under constitutional provisions; three have statutory authorization, HART \& WECHSLER, THE FEDERAL CoURTS AND THE FEDERAL System 77-81 (1953). See also Clovis \& Updegraff, Advisory Opinions, 13 IowA L. REv. 188, 194-96 (1928).

11. See generally, Clovis \& Updegraff, supra note 10 ; Ellingwood, DeParTMENTAL COOPERATton IN STATe Governanents (1918); Field, The Advisory OpinionAn Analysis, 24 IND. L.J. 203 (1949); Hudson, Advisory Opinions of National and International Courts, 37 HARv. L. REv. 970 (1924); Note, Why Not Advisory Opinions for Illinois?, 31 CHI-KeNT Rev. 141 (1953); Comment, The Advisory Opinion and the United States Supreme Court, 5 FORD. L. REv. 94 (1936).

12. Frankfurter, $A$ Note on Advisory Opinions, 37 HARV. L. REv. 1002, 1006 (1924). See also, Aumann, The Supreme Court and the Advisory Opinion, 4 OHro ST. L.j. 21 (1937); Frankfurter, Advisory Opinions in 1 ENCYc. Soc. Scr. 475 (1937).

13. For a proposal that the attorney-general of the jurisdiction be required to submit briefs on both sides of the question, see Clovis \& Updegraff, supra note 10, at 195 .

14. Davison, The Constitutionality and Utility of Advisory Opinions, $2 \mathrm{U}$. of ToRonto L.J. 254, 270 (1938); Freund, op. cit. supra note 7, at 109-10. Although advisory opinions are not, in theory, binding upon the court in later cases, BorCHARD, DECLARATORY JuDGMENTs 52 (1934), they have been described as "ghosts that slay." Frankfurter, supra note 12, at 1008 .

15. See FREUND, op. cit. supra note 7, at 84-85.

16. See generally, BorCHARD, op. cit. supra note 14, at 26-57; Diamond, Federal Jurisdiction to Decide Moot Cases, 94 U. of PA. L. REv. 125 (1946); RoBERTSON \& 
In most cases, since the plaintiff is the one who seeks to protect a legal right, he is the party whose interest will be lacking. Often, when a plaintiff is seeking mandatory or injunctive relief to prevent an impending harm, the inevitable delays of judicial administration will make the requested decree ineffectual to secure to the plaintiff that which he sought. ${ }^{17}$ For obvious reasons, courts prefer not to enter decrees which will have no effect on the present status of the parties, and will dismiss such cases in order to devote their time to the decision of live controversies, which do give relief to those whose rights have been violated. ${ }^{18}$ With the crowded condition of most dockets, economy of judicial endeavor becomes a second important reason for the mootness doctrine.

Mootness must be distinguished from abatement, which has been defined as the suspension or termination of all proceedings in a suit from the want of proper parties capable of proceeding therein. ${ }^{19}$ In a moot case only the legal interest of a party is lacking.

\section{Types of Moot CASES}

In some frequently recurring situations, mootness doctrines are easily applied.

Collusive and Fictitious Actions.-In a collusive suit, the appearance of an adversary contest is maintained for the purpose of securing a judgment desired by both parties; thus the proceeding presents a virtual fraud on the court. In Lord $v$. Veazie ${ }^{20}$ both plaintiff and defendant desired the same result, which would have foreclosed the rights of one not a party

KrRkHaMr, JuRISDiction of the SUPREMe Court of the United States 493-536 (Wolfson \& Kurland ed. 1951); STERN \& Grossman, op. cit. supra note 6, at 338-49; Note, 22 IND. L.J. 235 (1947); Note, 53 HARv. L. REv. 628 (1940); Note, 34 HARV. L. REv. 416 (1921).

Compare HARRIS, op. cit. supra note 1 , at 23 : such doctrines "are no more than trees behind which judges hide when they wish either to throw stones at Congress or the President or to escape from those who are urging them to do so. . . ."

17. E.g., Chandler v. Wise, 307 U.S. 474 (1939) ; Dunn v. Dunn, 96 Ind. App. 620, 185 N.E. 334 (1933) ; Bassett v. Armstrong, 309 Pa. 296, 163 Atl. 525 (1933); cf. Natural Milk Producers v. City and County of San Francisco, 317 U.S. 423 (1943); International Union v. Hoisting \& Portable Engineers, 231 Ind. 634, 110 N.E.2d 332 (1953). However, courts often render judgments which cannot be satisfied. BORCEARD, op. cit. supra note 14 , at 8 .

18. Van DeVegt v. Board of Comm'rs of Larimer County, 98 Colo. 161, 177, 55 P.2d 703, 710 (1936) (dissenting opinion); In re Norton, 158 N.Y. 130, 52 N.E. 723 (1899).

19. Bouvier, Law Dictionary 6 (Thira rev. 1914). See, e.g., Snyder v. Buck, 340 U.S. 15 (1950) (no substitution of official party after resignation), discussed thoroughly in Note, 50 MICH. I. REv. 443 (1952) ; Eisler v. United States, 338 U.S. 189, 883 (1949) (defendant fled jurisdiction), discussed in 48 MICE. L. REv. 111 (1949). Writs of habeas corpus will be dismissed when it appears that the petitioner is no longer in the custody of the defendant, who is thus not a proper party. United States ex rel. Innes v. Crystal, 319 U.S. 755 (1943); Zimmerman v. Walker, 319 U.S. 744 (1943). But see Ex parte Endo, 323 U.S. 283, 304-05 (1944). See also United States v. Johnson, 319 U.S. 503, 520 (1943) (death of defendant in criminal case abates the cause); Singer v. United States, 323 U.S. 338, 346 (1944); cf. Howard v. Wilbur, 166 F.2d 884 (6th Cir. 1948).

20. 8 How. 251 (U.S. 1850). See also French v. Jeffries, 149 F.2d 555 (7th Cir. 1945); Bryan v. Kales, 3 Ariz. 423, 31 Pac. 517 (1892) (plaintiff suing himself). 
to the action. On motion of the third party, the Supreme Court dismissed the suit as collusive.

Not quite as strong a case is that presented by the framed test case, which lacks the element of common desire for one outcome; but here too, the courts will refuse to hear and decide the legal issues involved. This situation has arisen, for example, where a suit to test the validity of an act of Congress was authorized by the act, and an appropriation was made to cover the attorneys' fees necessary for the suit.21 Cases where one party has acquired control over both sides of the action, ${ }^{22}$ or where the defendant has subsidized the suit through payment of the plaintiff's attorney's fees, ${ }^{23}$ also will not be decided. However, one case held that, although the plaintiff had written the defendant that any judgment obtained would not be executed against the defendant but would be used merely to establish the defendant's negligence to aid in collecting insurance, the case was not moot. There was no binding assurance that the plaintiff would not execute, principally because he might not be permitted to rely on the judgment in his subsequent suit against the insurance company. ${ }^{24}$ The doctrine of mootness does not preclude the decision of those test cases which are based on actual facts and in which control or the strong possibility of control by one party is absent, even though the parties may agree to certain steps which merely expedite the decision without influencing the result.

Settlement.-When the parties settle a controversy, the courts will dismiss the appeal upon motion of either. ${ }^{25}$ Economy of judicial endeavor requires dismissal here, for even the parties ordinarily have no interest in

21. Muskrat v. United States, 219 U.S. 346 (1911) (dismissed because the parties had no adverse interests); cf. In re Workmen's Comp. Fund, 224 N.Y. 13, 119 N.E. 1027 (1918).

In Norton v. Vesta Coal Co., 291 U.S. 641 (1934), the Government, after having applied for and having been granted certiorari on the ground that there was a conflict among the circuits, then adopted the position that the decision adverse to the Government in the lower court was correct. Certiorari was dimissed; no substantial controversy existed.

22. East Tennessee, Va. \& Ga. R.R. v. Southern Tel. Co., 125 U.S. 695 (1888). See also United States v. Johnson, 319 U.S. 302 (1943); cf. Fukunaga v. Fujino, 38 Hawaii 556 (1950).

23. Cf. San Mateo County v. Southern Pac. R.R., 116 U.S. 138 (1885). But cf. City and County of San Francisco v. Boyd, 22 Cal.2d 685, 140 P.2d 666 (1943) (attorney's fees for both plaintiff and defendant, comptroller of plaintiff, paid from public funds; held: since defendant was merely performing his duty to prevent improper expenditures and a real controversy existed, not collusive).

See Sun Life Assurance Co. of Canada v. Jervis, [1944] W.N. 91; Mathews v. Coca-Cola Co. of Canada, Itd., [1944] Can. Sup. Ct. 385; both cases discussed in 22 CAN. B. REv. 547 (1944). See also Halligan v. Davis, 64 Ir. L.T.R. 117, [1930] I.R. 237.

24. Reynolds v. Van Culin, 36 Hawaii 556, 560-63 (1943).

25. Stewart v. Southern Ry., 315 U.S. 283, 784 (1942) (on rehearing); Danciger Oil \& Refining Co. v. Smith, 290 U.S. 599 (1933) (stipulation); Dakota County v. Glidden, 113 U.S. 222 (1885); Willis v. Buchman, 240 Ala. 386, 199 So. 892 (1940) ; State ex rel. Robinson v. Boniecki, 223 Ind. 416, 61 N.E.2d 176 (1945). 
the outcome of the suit.. ${ }^{26}$ However, in one case, the United States Supreme Court dismissed the appeal in a bitterly contested rate controversy, on the ground that the case had been settled when the competing carriers accepted an ICC compromise rate designed to be effective only until a court decision could be obtained. ${ }^{27}$ It would seem that the Court in this case was somewhat overzealous in applying the restrictive rule.

Preliminary Orders.-In some cases, while the appeal from a preliminary court order is pending, the main issue in the case will be decided or settled, or may be before the same court in a separate appeal. Then, the first appeal is moot. ${ }^{28}$

Multiple Legal Theories. - Where more than one legal basis for a cause of action or defense is in issue, and one is decided which is determinative of the case, the second is moot and need not and will not be decided.29 For example, where the plaintiff opposed the registration of the defendant's trademark on the ground that a possibility of confusion existed and registration was denied on the ground that the trademark was not registerable, the issue of confusion was held to be moot; the plaintiff had already obtained that which he sought in bringing the action. ${ }^{30}$ If a lower court rules on the extraneous matter, it will not be considered on appeal, although the decree may be reformed to eliminate the unnecessary portion. ${ }^{31}$

Lapse of Time.-Mere lapse of time will sometimes cause a case to become moot. This is especially true in suits seeking mandatory or injunctive

26. Even though the court costs have not been settled, this is not sufficient interest in the outcome to enable the court to decide the case. See cases cited note 39 infra. Cf. International Union of Operating Engineers v. Hoisting \& Portable Engineers Union, 231 Ind. 634, 110 N.E.2d 332 (1953).

27. United States v. Anchor Coal Co., 279 U.S. 812 (1929). For the facts, see Arnold, supra note 1, at 915.

28. Royal Cadillac Service, Inc. v. United States, 317 U.S. 595 (1942) (effect of application on interim operation, application denied) ; Sterling v. Constantin, 287 U.S. 378, 386 (1932) (appeal from grant of temporary injunction, appeal from final decree before the court); Champlin Refining Co. v. Corporation Comm'n of Oklahoma, 286 U.S. 210, 224 (1932) (same) ; Chicago \& V. R.R. v. Fosdick, 106 U.S. 47, 84 (1882) (appeal from execution of decree, decree reversed); People v. Redlich, 402 Ill. 270, 80 N.E.2d 736 (1949) (order for psychological examination, defendant convicted of crime); New Orleans v. Vinci, 153 La. 528, 96 So. 110 (1923) ; Humann v. Rivera, 272 App. Div. 352, 71 N.Y.S.2d 321 (1st Dep't 1947) (denial of motion for new trial, conviction reversed) ; Fitzgerald v. State, 188 P.2d 412 (Okla. Crim. App. 1947) (appeal of conviction, new trial granted); Huffman v. Alexander, 197 Ore. 283, 251 P.2d 87 (1952), rehearing denied, 197 Ore. 331, 253 P.2d 289 (1953) (habeas corpus, conviction reversed); Shinn v. Stemmler, $159 \mathrm{~Pa}$. Super. 129, 47 A.2d 294 (1946) (effect of administrative order pending appeal, order affirmed). Cf. Cheong Ah Moy v. United States, 113 U.S. 216 (1885) (habeas corpus, prisoner deported). See Fisher v. Baker, 203 U.S. 174, 181 (1906). In United States ex rel. Norwegian Nitrogen Products Co. v. United States Tariff Comm'r, 274 U.S. 106 (1927), the Court refused to review the fairness of an administrative hearing held for the purpose of making a recommendation to the President on tariff rates when it appeared that the President had acted on the recommendation and had set new rates, a "political," non-reviewable act.

29. Gibbes v. Zimmerman, 290 U.S. 326, 333 (1933); Lewis v. United States, 216 U.S. 611 (1910); cf. Brownlow v. Schwartz, 261 U.S. 216 (1923).

30. Frankfort Distilleries v. Dextora Co., 103 F.2d 924 (C.C.P.A. 1939).

31. Electrical Fittings Corp. v. Thomas \& Betts Co., 307 U.S. 219 (1939). See cases cited note 136 infra. 
relief, as where the plaintiff sought specific performance of a covenant not to compete for one year, and the year had expired by the time the appeal was heard. ${ }^{32}$ Recently, in Doremus v. Board of Education, ${ }^{33}$ the Supreme Court held that a parent who complained that his child was being subjected to an unconstitutional requirement of Bible reading had a moot case when the child graduated. A case chosen to test the constitutionality of the Child Labor Act was held to be moot when it was shown that the child had reached an age no longer subject to the provisions of the Act. ${ }^{34}$ Thus, it is apparent that often in injunction cases the person who wins in the lower court has won the case, for all appeal will be cut off by the doctrine of mootness if the action sought to be restrained was a single act or a series of acts taking but a short time, or if the injunction was needed for only a short time. $^{35}$ There is no way in these cases to preserve the right of appeal, for to maintain the status quo is, in effect, to grant the injunction; however, mitigating doctrines have been developed which are discussed below. ${ }^{36}$

In other recurrent situations, the application of mootness doctrines presents more difficult problems.

Other Relief Possible.-In some instances, although the principal relief sought has become unobtainable because of mootness, the plaintiff may have included a count which has not been affected and which remains vital, or may be able to amend his complaint to seek relief which it still is possible to grant, generally money damages. ${ }^{37}$ Possibly the defendant may be liable for penalties or reparations. ${ }^{38}$ Costs incurred in the prosecution of the case

32. E.g., Standard Dairies v. McMonagle, $139 \mathrm{~Pa}$. Super. 267, 11 A.2d 535 (1939). Accord, Stern v. Stern, 327 Mich. 531, 42 N.W.2d 737 (1950) (court order sought to enable parent to have child's visit in August, 1949, case decided May, 1950). See Poole v. Giles, 248 S.W.2d 464 (Tex. 1952) (dissenting opinion), for discussion of this problem.

33. 342 U.S. $429,423-33$ (1952).

34. Atherton Mills v. Johnston, 259 U.S. 13, 15-16 (1922).

35. Benz v. Compania Naviera Hidalgo, 205 F.2d 944 (9th Cir. 1953); Stern v. Stern, 327 Mich. 531, 42 N.W.2d 737 (1950).

36. These doctrines are discussed herein as continuing controversies (text at notes 73-104 infra) and public interest (text at notes 105-36 infra).

37. Standard Fashion Co. v. Magrane-Houston Co., 258 U.S. 346, 353 (1922) (damages capable of partial assessment); Papaliolios v. Durning, 175 F.2d 73 (2d Cir. 1949) (complaint treated as amended); Dakota Coal Co. v. Fraser, 267 Fed. 130 (8th Cir. 1920) (case remanded with leave to amend); Martin v. American Potash \& Chemical Corp., 92 A.2d 295 (Del. 1952). In Heitmuller v. Stokes, 256 U.S. 359 (1921), and State ex rel. Robinson v. Boniecki, 223 Ind. 416, 61 N.E.2d 176 (1945), probably the plaintiff could also have pursued an action for damages for unlawful possession of the real estate whose possession was in issue, although the issue was not raised in either case.

38. Southern Pacific Co. v. ICC, 219 U.S. 433 (1911) (reparations) ; Oklahoma City v. Sanders, 94 F.2d 323 (10th Cir. 1938) (penalties); Moore v. Smith, 160 Kan. 167, 160 P.2d 675 (1945) (damages). But cf. Kiker v. City of Wewoka, 205 Okla. 90, 235 P.2d 710 (1951) (public interest exception, see text at notes 105-36 infra, does not apply where plaintiff, in moot suit for injunction, may seek damages in another action). Multiplicity of actions may be avoided by treating the complaint as amended on appeal, as in Papaliolios v. Durning, $175 \mathrm{~F} .2 \mathrm{~d} 73$ (2d Cir. 1949). 
are generally held not sufficient to enable the court to retain jurisdiction and decide the case. ${ }^{39}$

Obviously, it frequently will be possible to present the argument that the plaintiff might be entitled to some other relief. Judicial discretion must be exercised to limit the effectiveness of this argument to the unusual case, and appeals have been dismissed where the additional relief sought was found to be merely ancillary to the relief now impossible to grant. ${ }^{40}$ By including a count for damages in his original complaint, the plaintiff may be able to avoid the ancillary doctrine, which seems to have been applied only in cases in which the alternative relief was sought merely as an afterthought after the case had become moot. Applicable procedural rules must, of course, be consulted to determine the propriety of such joinder of legal and equitable relief.

Satisfaction of Criminal Sentences.-Under the majority rule, one who has paid his fine or served his full prison term cannot prosecute an appeal of the judgment of his conviction. ${ }^{41}$ Many of these courts hold that defendants in these situations have waived the right to appeal, which therefore makes a subsequent appeal moot. ${ }^{42}$ Since the waiver argument is essentially a mere legal conclusion, the problem is better expressed as a judicial determination of what minimum interest in the outcome of the appeal must remain in the defendant to prevent the case from becoming

39. E.g., Chaitlen v. Kaspar Am. State Bank, 372 Ill. 83, 22 N.E.2d 673 (1939); In re Kaeppler, 7 N.D. 307, 75 N.W. 253 (1898). Contra: State ex rel. Strike v. Racine, 201 Wis. 435, 230 N.W. 70 (1930); cf. Piper v. Hawley, 179 Cal. 10, 175 Pac. 417 (1918) (costs and damages).

In Heitmuller v. Stokes, 256 U.S. 359 (1921), the Court awarded costs to the defendant, since the plaintiff was responsible for the case being moot.

40. Alejandrino v. Quezon, 271 U.S. 528, 532 (1926) ; Lewis Pub. Co. v. Wyman, 228 U.S. 610 (1913); cf. Benz v. Compania Naviera Hidalgo, 205 F.2d 944 (9th Cir. 1953).

41. E.g., St. Pierre v. United States, 319 U.S. 41 (1943) ; Bergdoll v. United: States, 279 Fed. 404 (3d Cir. 1922).

See Rogers, Payment of Fine in Criminal Case as Affecting Right to Reviezu Conviction, 35 LAW Notes 31 (1931); Note, Criminal Law: Recovery of Fines Paid for Violations of a Statute Subsequently Declared Unconstitutional, 2 OKLA. I. REv. 351 (1949); Comment, 59 YaLE L.J. 786 (1950); Annot., 74 A.L.R. 638 (1931) ; Annot., 18 A.I.R. 867 (1922).

In most instances, criminal appeals which become moot on this ground are for minor crimes, since substantial sentences will not have been completely served by the time the appeal is heard. However, in Director of Prisons v. Court of First Instance of Cavite, 239 U.S. 633 (1915), the death sentence was inflicted before the appeal was heard. The appeal was dismissed as moot.

42. State v. Westfall and Mathews, 37 Iowa 575 (1873); State v. Conkling, 54 Kan. 108, 37 Pac. 992 (1894) ; People v. Melovicz, 221 Mich. 620, 192 N.W. 562 (1923) ; Washington v. Cleland, 49 Ore. 12, 88 Pac. 305 (1907); Commonwealth v. Gipner, $118 \mathrm{~Pa} .379,12$ Atl. 306 (1888). Compare People v. Pyrros, 323 Mich. 329, 35 N.W.2d 281 (1948), with 1943-44 ReP. OF ATT'y GEN. of MicH. 528.

In St. Pierre v. United States, 319 U.S. 41 (1943), the Court indicated that St. Pierre's failure to apply for supersedeas pending the outcome of his appeal was an important factor in the decision.

"These decisions, it seems to us, lose sight of, or purposely ignore, that damaging effect of such a judgment which everybody knows reaches far beyond its satisfaction by payment of a fine or serving a term of imprisonment." State v. Winthrop, 148 Wash. 526, 534, 269 Pac. 793, 797 (1928). See text at note 58 and note 58 infra. 
moot. ${ }^{43}$ At present, a minority of jurisdictions have considered such appeals on the merits.

A factor frequently stressed in the majority decisions is that the judgment of the court could not restore to the defendant that which he lost through his allegedly improper conviction. ${ }^{44}$ Obviously, the court cannot give back the time spent in jail, and in many states a fine paid under a mistake cannot be recovered. ${ }^{45}$ Conversely, where, by constitutional provision, the governor has the power to remit fines and forfeitures for offenses against the state, it has been held that payment of a fine did not deprive the defendant of his right to appeal.46 Payment of a fine does not necessarily indicate real acquiescence in the judgment, ${ }^{47}$ and, where the fine has been paid under protest ${ }^{48}$ or by a third person, ${ }^{49}$ such payment is not even evidence of acquiescence by the defendant. Except for judicial unwillingness to issue an order which cannot undo the material harm done to the wrongfully-convicted appellant, ${ }^{50}$ there seems to be no reason why the inability to recover amounts paid by mistake should be controlling. ${ }^{51}$ Particularly in criminal cases, the defendant ${ }^{52}$ has a great interest in clearing his name of the stigma of a conviction.53 A small segment of the minority decisions have recognized this interest as the sole interest necessary to

43. "There is no basis in fact for the contention that he waives his appeal, for the thing done bears no inconsistent relation to the thing to be done, so there is not factually an election." People v. Chamness, 109 Cal. App. 778, 780, 288 Pac. 20, 21 (App. Dep't 1930). See Village of Avon v. Popa, 121 N.E. 2d 254 (Ohio Ct. App. 1953).

44. "We agree ... that a 'good name is better than riches.' Its loss or impairment is a melancholy disaster to anyone who values it. But we do not perceive how we can revive a dead judgment for the purpose of quieting title to a good reputation." State v. Cohen, 45 Nev. 266, 201 Pac. 1027 (1921).

45. E.g., Ferguson v. Butler County, 297 Mo. 20, 247 S.W. 795 (1923) ; State v. Westfall and Mathews, 37 Iowa 575 (1873).

46. Duncan v. State, 190 Md. 486, 58 A.2d 906 (1948); cf. Bower v. State, 135 N.J.I. 564, 53 A.2d 357 (Sup. Ct. 1947) (recovery of fine permitted by judicial decision).

47. Johnson v. State, 172 Ala. 424, 55 So. 226 (1911) ; Commonwealth v. Fleckner, 167 Mass. 13, 44 N.E. 1053 (1896). For an example of acquiescence, see State v. People's Ice Co., 127 Minn. 252, 149 N.W. 286 (1914).

48. Papaliolios v. Durning, 175 F.2d 73 (2d Cir. 1949).

49. Metcalf v. Drew, 75 Cal. App.2d 711, 171 P.2d 488 (1946); Ishpeming v. Maroney, 49 Mich. 226 (1882) (alternative holding). But cf. Eutsler v. Commonwealth, $154 \mathrm{Ky} .35,156$ S.W. 855 (1913) (fine paid by defendant's wife).

50. See text following note 17 supra.

51. Johnson v. State, 172 Ala. 424, 55 So. 226 (1911). The inability to recover fines prevents analogy to civil cases, in which it is uniformly held that payment of a judgment does not necessarily constitute waiver of the right to appeal, since, in such cases, the amount paid may be recovered from the judgment holder if the appeal is successful. Morfessis v. Marvins Credit, Inc., 77 A.2d 178 (D.C. Mun. Ct. App. 1950).

52. ". . . [I]t seems to us that the next-of-kin of a convicted person who dies pending an appeal have an interest in clearing his good name, which Congress might well believe would justify a change in the law." United States v. Mook, 125 F.2d 706 (2d Cir. 1942). Cf. Rose v. Daily Mirror, 284 N.Y. 335, 31 N.E.2d 182 (1940).

53. State v. Winthrop, 148 Wash. 526, 269 Pac. 793 (1928) ; accord, Matter of Lincoln, 102 Cal. App. 733, 283 Pac. 965 (1929) ; People v. Marks, 64 Misc. 679, 120 N.Y.S. 1106 (Ct. Gen. Sess. 1909). 
allow an appeal. ${ }^{54}$ Most of the minority courts, however, require more than just an interest in reputation. ${ }^{55}$ In an early New York case, the court allowed an appeal partly because the defendant's conviction of criminal libel, based on a book he had published, would decrease the profits from the sale of the book..$^{56}$ If the defendant is threatened with deportation stemming from conviction of a crime involving moral turpitude, it has been held that an appeal from his conviction may be heard, even though his sentence has been served. . $^{\text {t7 }}$

Some states, by constitutional provision or by statute, withdraw certain civil rights, most usually the right to vote or hold office, from persons convicted of certain crimes. ${ }^{58}$ Also, one's standing to pursue certain professions may be impaired by a criminal conviction. ${ }^{59}$ In such states, a very real harm from the allegedly improper conviction may continue long after the sentence has been satisfied, and therefore the defendant's appeal should be heard. ${ }^{60}$ Many jurisdictions have criminal registration statutes or ordinances ${ }^{61}$ and habitual criminal statutes which would impose an additional burden. ${ }^{62}$ In the courts which require more than an interest in reputation in order to hear an appeal, ${ }^{63}$ the above multifarious legal interests and loss of rights of a convicted person should provide the added

54. California has recognized this interest often: In re Byrnes, 26 Cal.2d 824, 161 P.2d 376 (1945); People v. Becker, 108 Cal. App.2d 764, 239 P.2d 898 (1952) (recognizing the trend in that state); People v. Chamness, 109 Cal. App. 778, 288 Pac. 20 (App. Dep't 1930). See also People v. Marks, 64 Misc. 679, 120 N.Y.S. 1106 (Ct. Gen. Sess. 1909); Village of Avon v. Popa, 121 N.E.2d 254 (Ohio Ct. App. 1953); Roby v. State, 96 Wis. 667, 71 N.W. 1046 (1897).

55. See cases cited in note 41 supra.

56. Barthelemy v. People, 2 Hill 248, 256 (N.Y. 1842).

57. Fiswick v. United States, 329 U.S. 211 (1946) ; State ex rel. Lopez v. Killigrew, 202 Ind. 397, 174 N.E. 808 (1931). But cf. McCarthy v. Wayne County Circuit Judge, 294 Mich. 368, 293 N.W. 683 (1940) (policeman indefinitely suspended as a result of contempt of court conviction, but evidence of suspension not in record).

58. E.g., Mo. Const. Art. VIII, §2; Mo. Rev. Stat. \$111.060 (1949); FLa. Const. Art. 6, \$4. See Crawford, Discretionary Relief from Consequences of Criminal Convictions in Missouri, 28 WASH. U.L.Q. 74, 77-78 (1943); Gathings, Loss of Citizenship and Civil Rights for Conviction of Crime, 43 AM. POL. SCI. REv. 1228 (1949); Holtzoff, Loss of Civil Rights by Conviction of Crime, 6 Fed. Probation 18 (1942); Comment, 26 So. Calif. L. Rev. 425 (1953). However, only the most serious crimes are punished in this manner, and most severe criminal sentences will not be satisfied before an appeal can be heard.

59. Note, 59 Yale L.J. 786 (1950).

60. In such a case, the defendant "has a substantial stake in the judgment of conviction which survives the satisfaction of the sentence imposed on him." Fiswick v. United States, 329 U.S. 211, 222 (1946) ; State v. Smiley, 98 Mo. 605, 12 S.W. 247 (1889).

61. Note, Criminal Registration Ordinances: Police Control Over Potential Recidivists, 103 U. of PA. L. Rev. 60, 65 (1954). Some of these ordinances apparently apply even to minor crimes, $i d$. at 67 .

62. State v. Jacobson, 348 Mo. 258, 152 S.W.2d 1061 (1941). Defendant accepted a pardon proffered because the Governor was convinced of his innocence. Even though this type of pardon carries no imputation of guilt, see Crawford, supra note 58, at 77-78, it was held that sufficient controversy still existed to prevent the appeal from being moot. But cf. State v. Stout, 258 Pac. 1054 (Okla. Crim. App. 1927), 41 HARV. L. REV. 534 (1928).

63. See 1943-44 Rep. of ATT'y GeN. of Mrch. 528; cf. Rose v. Daily Mirror, 284 N.Y. 335,31 N.E.2d 182 (1940). 
impetus necessary to overcome the barrier of mootness. ${ }^{64}$ Because of these further threats to a defendant's freedom after a sentence has been served, this area does not seem an appropriate one to apply mootness for economy reasons. In addition, the interests of a defendant and of a state in the result of such an appeal would seem to be sufficiently strong to insure truly adversary argument.

Expiration of Licenses.-Another frequently recurring situation is that an appeal from the refusal to renew or issue a short-term license is not heard until the license would have expired. Formerly, the appeal would be dismissed as presenting no issue upon which the judgment of the court could operate, i.e., dismissed because moot. ${ }^{65}$ Most courts today will look farther than the immediate effect of the expiration and will hear the appeal on the merits whenever the denial of the license will have a future effect on the applicant. ${ }^{66}$ This includes cases in which no license may be issued for a specified period of time after revocation or denial of renewal, ${ }^{67}$ cases in which the licensee can show a continuing interest in conducting a business or profession, ${ }^{68}$ cases which involve licenses of so short a term that appellate review could almost never be obtained under the old rule, ${ }^{69}$ and other cases in which loss of license would have other serious detrimental effects. ${ }^{70}$ This rule, in granting review where the applicant can show an effect upon an interest other than his good name as a licensee, is clearly analogous to the rule developed in the cases dealing with satisfaction of criminal sentences. ${ }^{71}$ Some courts have also expressed the fear that to

64. It does not appear that this point was specifically rejected by any of the decisions. It has been held that an habitual criminal statute provides an adequate basis to permit "a motion in the nature of a writ of error coram nobis" in the federal courts. United States v. Morgan, 346 U.S. 502, 505 (1954).

65. E.g., Security Mut. Life Ins. Co. v. Prewitt, 200 U.S. 446 (1906) ; Travelers Ins. Co. v. Prewitt, 200 U.S. 450 (1906).

66. E.g., Heuston v. Gilman, 98 Colo. 301, 56 P.2d 40 (1936) ; Burke v. Coleman, 356 Mo. 594, 202 S.W.2d 809 (1947); Drozdowski v. Mayor and Council of Sayreville, 134 N.J.I. 566, 49 A.2d 476 (Sup. Ct. 1946). See also cases cited notes 67-70 infra.

67. Barretta v. Cocreham, 210 La. 55, 26 So.2d 286 (1946); Seila's Liquor License Case, 124 Pa. Super. 519, 190 Atl. 203 (1937) ; Revocation of Wolf's License, $115 \mathrm{~Pa}$. Super. 514, 176 Atl. 260 (1935).

68. Leonard \& Leonard v. Earle, 279 U.S. 392 (1929); Leakey v. Georgia Real Estate Comm'n, 80 Ga. App. 272, 55 S.E.2d 818 (1949) ; State v. Otterholt, 234 Iowa 1286, 15 N.W.2d 529 (1944). See In re Carter, 192 F.2d 15, 29 (1951) (concurring opinion) ; cf. Gilchrist v. Bierring, 234 Iowa 899, 914-15, 14 N.W.2d 724, 731-32 (1944).

Where the period of the ban on getting a new license had also expired, a court declared the suit moot: Rayahel v. McCampbell, 55 F.2d 221 (2d Cir. 1932).

69. Technical Radio Laboratory v. Federal Radio Comm'n, 36 F.2d 111 (D.C. Cir. 1929) (renewal valid for only three months); Close v. Southern Md. Agric. Ass'n, 134 Md. 629, 108 Atl. 209 (1919) (thirteen day racing meeting); Peppers Refining Co. v. Corporation Comm'n, 198 Okla. 451, 179 P.2d 899 (1947).

70. Feight v. State Real Estate Comm'n, 151 Neb. 867, 39 N.W.2d 823 (1949) (stigma of conviction); Miller v. Lutheran Conf. and Camp Ass'n, $331 \mathrm{~Pa}$. 241, 200 At1. 646 (1938).

71. See text at notes 55-64 supra. 
deny review of such actions could lead to abuses by administrative agencies in the enforcement of licensing statutes. ${ }^{72}$

\section{Continuing Controversies}

The federal courts have developed a doctrine which permits the decision of certain cases which otherwise would be dismissed as moot. They will decide a case which is moot on its exact facts, but which represents a continuing controversy between the parties which has not been settled ${ }^{73}$ and which is likely to remain unsettled without the decision. ${ }^{74}$ This theory was prompted in part by the same fear of administrative abuses which was a guiding factor in establishing the present rule regarding license cases. ${ }^{75}$ The foundation of the continuing controversy doctrine is Southern Pacific Terminal Co. v. ICC, ${ }^{78}$ in which the validity of an ICC cease and desist order, limited by its own terms to two years, was challenged as outside the authority of the Commission. The Court, in holding that it could review the validity of the order even though the two year limit had expired, said:

"The questions involved in the orders of the Interstate Commerce Commission are usually continuing (as are manifestly those in the case at bar) and their consideration ought not to be, as they might be, defeated, by short term orders capable of repetition, yet evading review, and at one time the Government and at another time the carriers have their rights determined by the Commission without a chance of redress." 77

Where an administrative ruling which has been suspended probably will be reinstated, the same rule applies, and the court will hear the appeal. ${ }^{78}$

72. Kenworthey \& Taylor, Inc. v. State Examiners of Electricians, 320 Mass. 451, 70 N.E.2d 247 (1946), and cases cited in note 117 infra.

73. Cf. United States v. Anchor Coal Co., 279 U.S. 812 (1929). See text at notes 25-27 supra.

74. Porter v. Lee, 328 U.S. 246 (1946); Walling v. James V. Reuter, Inc, 321 U.S. 671, 675 (1944); Papaliolios v. Durning, 175 F.2d 73 (2d Cir. 1949); Morris v. Williams, 149 F.2d 703 (8th Cir. 1945); United States v. Railway Employees' Dep't, AFL, 286 Fed. 228 (N.D. I1l. 1923) ; Boise City Irr. \& Land Co. v. Clark, 131 Fed. 415, 418-19 (9th Cir. 1904). But of. St. Pierre v. United States, 319 U.S. 41 (1943). Some state courts have also adopted this rule. See, e.g., New Bedford v. New Bedford, Woods Hole, etc. S.S. Authority, 330 Mass. 422, 114 N.E.2d 553 (1953).

75. See text at and following note 65 supra. (1911).

76. 219 U.S. 498 (1911). See also Southern Pacific Co. v. ICC, 219 U.S. 433

77. 219 U.S. at 515. Cited as authority for the decision were United States v. Trans-Missouri Freight Ass'n, 166 U.S. 290 (1897), discussed following note 83 infra, and Boise City Irr. \& Land Co. v. Clark, 131 Fed. 415 (9th Cir. 1904), which, in alternative holdings, applied both the continuing controversy theory and the public interest theory. See text at notes 105-36 infra.

78. United States v. Rock Royal Cooperative, Inc., 307 U.S. 533, 555-56 (1939); Panama Refining Co. v. Ryan, 293 U.S. 388, 412-14 (1935); Gay Union Corp. v. Wallace, 112 F.2d 192 (D.C. Cir. 1940), cert. denied, 310 U.S. 647 (1940); Yarneli v. Hillsborough Packing Co., 70 F.2d 435, 438 (5th Cir. 1934); cf. Ford Motor 
An important element of these cases seems to be the likelihood of repetition of the order directed against the identical conduct involved in the case at bar. ${ }^{79}$ However, an unfortunate tendency seems to exist in some of the opinions not to emphasize this element, especially where the order is one which theoretically extends to future conduct and is designed to protect the rights of the public, ${ }^{80}$ but to decide the cases as continuing controversies merely because the parties are still at odds over the legality of an order which most likely will never be repeated. This tendency is particularly prevalent in cases involving orders issued by the National Labor Relations Board and the Federal Trade Commission, which are considered by the courts even though the immediate object of the order has been accomplished or has become impossible of accomplishment. ${ }^{81}$ Such orders are generally broadly phrased and are directed at the prevention of future violations; thus they fit within the broad definition of continuing controversies despite the lack of the guarantee of an adverse interest in the one person to whom the order was directed. However, it seems unlikely that courts would be willing to cede so important an area of government regulation to the agencies involved merely because many of the appeals from these orders are technically moot; judicial review over these important agencies would then become spotty and irregular.

Voluntary Cessation.- The archetype of the continuing controversy doctrine exists where the defendant has voluntarily ceased activity alleged to be violative of the plaintiff's rights. ${ }^{82}$ The original case on the subject is United States v. Trans-Missouri Freight Association, ${ }^{83}$ which was an injunction proceeding, under the Sherman Act, against an allegedly unlawful combination. The defendant won in the trial court and court of appeals, and then dissolved. It never admitted the illegality of the combination, nor professed any intention to recombine, but it did argue that its dissolution was for a purpose other than evasion of the pending action. The Supreme Court held that the case was not moot, stating that the rights of the public, which the Government was seeking to enforce, should not be foreclosed merely because the defendant voluntarily ceased its allegedly illegal activities. The Court's principal concern seemed to be

Co. v. United States, 335 U.S. 303, 313 (1948). Analogous state court decisions: Peppers Refining Co. v. Corporation Comm'n, 198 Okla. 451, 179 P.2d 899 (1947) ; New Bedford v. New Bedford, Woods Hole, etc. S.S. Authority, 330 Mass. 422, 114 N.E.2d 553 (1953); Doering v. Swoboda, 214 Wis. 481, 253 N.W. 657 (1934). See also cases cited throughout the public interest section, at notes 105-36 infra.

79. Southern Pacific Terminal Co. v. ICC, 219 U.S. 498 (1911).

80. See Campbell Soup Co. v. Martin, 202 F.2d 398 (3d Cir. 1953).

81. FTC v. Goodyear Tire \& Rubber Co., 304 U.S. 257, 260 (1938) ; Chamber of Commerce v. FTC, 13 F.2d 673, 686 (8th Cir. 1926); Guarantee Veterinary Co. v. FTC, 285 Fed. 853,859 (2d Cir. 1922) ; NLRB v. Crompton-Highland Mills, Inc., 337 U.S. 217, 225 (1949) ; NLRB v. E. C. Atkins \& Co., 331 U.S. 398 (1947); NLRB v. Pennsylvania Greyhound Lines, 303 U.S. 261, 271 (1938).

82. See Diamond, Federal Jurisdiction to Decide Moot Cases, 94 U. of PA. L. REv. 125, 135-37 (1946).

83. 166 U.S. $290,307-10$ (1897). 
that the defendant would reorganize ${ }^{84}$ and, by repeated dissolution and reorganization, completely evade the Sherman Act.

Recently, it has been held that if the defendant can demonstrate that "there is no reasonable expectation that the wrong will be repeated," the case will be dismissed as moot. ${ }^{85}$ Where the activity was stopped because of circumstances beyond the control of the parties, ${ }^{86}$ or where the cause of the cessation was obviously unrelated to the litigation, ${ }^{87}$ the cases have been dismissed. Of course, where the plaintiff has prevailed below and the activity has been terminated pursuant to court decree, the appeal will be heard. ${ }^{88}$

Repeal of Statutes.-When a statute has been repealed without a saving clause, proceedings begun under it are moot. ${ }^{89}$ Generally, it is mere speculation to say that a statute may be reenacted, and the courts will insist that a more probable issue be presented.90 However, where a new statute has been passed which will present substantially the same issues as are before the court in a case under the repealed statute, the case has been held to be of a continuing nature.91 In FTC v. Goodyear Tire \& Rubber $\mathrm{Co}^{.92}$ the defendant was charged with making a certain contract granting a preference alleged to be unfair under the Clayton Act. The defendant denied that the contract violated that Act. During pendency of the action, the Robinson-Patman Act, which obviously banned the contract, was passed, and the defendant abandoned it. However, both plaintiff and defendant desired to obtain a Supreme Court ruling on the Clayton Act question. The Court held that "neither the transactions subsequent

84. At least some of the members of the defendant association had formed another association. Id. at 305-06, 308-09.

85. United States v. W. T. Grant Co., 345 U.S. 629, 633 (1953), in which the district court had found as a fact that the wrong would not be repeated even though, after five years of administrative urging, the defendant refused to admit the illegality of its practice or to promise not to repeat it. This qualification was developed in Walling v. Youngerman-Reynolds Hardwood Co., 325 U.S. 419 (1945) (voluntary discontinuance of disputed labor contract); Standard Oil Co. (Indiana) v. United States, 283 U.S. 163, 181-82 (1931) (voluntary cancellation of objectionable contract terms). But cf. Walling v. Helmerich \& Payne, Inc., 323 U.S. 37, 42-43 (1944) (voluntary discontinuance of disputed labor contract).

86. United States v. Hamburg-Amerikanische Packetfahrt-Actien Gesellschaft, 239 U.S. 466, 475-78 (1916) ; United States v. American-Asiatic Steamship Co., 242 U.S. 537 (1917). But cf. United States v. Aluminum Co. of America, 148 F.2d 416, 448 (2d Cir. 1945).

87. Cf. Duncan v. Kahanamoku, 327 U.S. 304,312 n.5 (1946) ; Fisher v. Baker, 203 U.S. 174, 181 (1906).

88. Bakery Sales Drivers v. Wagshal, 333 U.S. 437, 442 (1948); cf. Eagles v. United States ex rel. Samuels, 329 U.S. 304, 306-08 (1946); Commercial Cable Co. v. Burleson, 250 U.S. 360 (1919) (activity terminated pursuant to presidential decree).

89. United States v. Alaska S.S. Co., 253 U.S. 113 (1920); Flanigan v. Sierra County, 196 U.S. 553 (1905); State ex rel. Bennett v. Brown, 216 Minn. 135, 12 N.W.2d 180 (1943); cf. Western Union Tel. Co. v. Louisville \& N.R.R. 258 U.S. 13 (1922). See also, United States v. Chambers, 291 U.S. 217, 222-23 (1934) (repeal of 18th Amendment rendered prosecution moot).

90. Spreckels Sugar Co. v. Wickard, 131 F.2d 12 (D.C. Cir. 1941).

91. Cf. Campbell v. California, 200 U.S. 87, 92-93 (1906). When no possibility of the same harm exists under the amended act, the case is moot. Berry v. Davis, 242 U.S. 468 (1917) ; Dinsmore v. Southern Express Co. and Ga. R.R. Comm'n, 183 U.S. 115 (1901).

92. 304 U.S. 257 (1938), reversing 92 F.2d 677 (6th Cir. 1937). 
to that order nor the passage of the amendatory Act deprived the respondent of its right to challenge the order and to have its validity determined." 93 Although the Robinson-Patman Act had a saving clause, and although the order in question was a cease and desist order styled by the Court as "continuing," it is submitted that the only contingency under which the order could have any practical significance is if the Robinson-Patman Act were to be repealed, which, it would seem, is no less speculative than the contingency that a repealed act will be reenacted.

Election Cases.-Cases involving election laws and procedures would seem to fall within the continuing controversy doctrine, but the courts have not so held. Voters who were being disenfranchised have sued in equity for mandatory or injunctive relief. Often, too, candidates have resorted to the courts to secure a place on the ballot for either primary or general elections, to secure recounts of the votes or to challenge other alleged irregularities in election procedures. ${ }^{94}$ Frequently, by the time these cases reached the Supreme Court, the election had been held or the term of office which the plaintiff sought had expired.95 Even if the election had not been held, the intervening time might be so short that no decree could give the relief requested. ${ }^{96}$ It would seem that where the plaintiff is seeking the right to vote in all elections, as when he alleges that the procedures followed by his state are unconstitutional, his standing to secure judicial review of the denial of this continuing right should not be lost merely because the legal machinery is slow. Where a candidate seeks a place on the ballot for a particular election, a decision in his favor after the election probably will do him no good. ${ }^{97}$ But where the procedure for placing minority parties on the ballot has been challenged, and there is the likelihood that the same minority party will be seeking such a place in the future, it would be desirable to decide the question under the continuing controversy doctrine. ${ }^{98}$ In Cole v. Chief of Police of Fall River, ${ }^{99}$ the plaintiff was a candidate for public office who sought to enjoin the defendant from enforcing a local ordinance which the latter contended unconstitutionally prohibited the method of campaigning used by the plaintiff. By the time the case reached the state supreme court, the plaintiff had lost the election. Although he claimed that he would seek other offices and desired to use the same campaign methods in the future, his case was dismissed as moot.

93. Id. at 260 .

94. Shub v. Simpson, 340 U.S. 861 (1950) ; MacDougall v. Green, 335 U.S. 281, 284 (1948) (concurring opinion); DeHoff v. Imeson, 153 Fla. 553, 15 So.2d 258 (1943); Brown v. Lieb, $267 \mathrm{~Pa} .24,110$ Atl. 463 (1920).

95. Mills v. Green, 159 U.S. 651 (1895) ; Cook v. Fortson, 329 U.S. 675 (1946) ; Love v. Griffith, 266 U.S. 32 (1924); Jones v. Montague, 194 U.S. 147 (1904); DeHoff v. Imeson, 153 Fla. 553, 15 So.2d 258 (1943).

96. Ex parte James, 287 U.S. 572 (1932) ; Sartin v. Barlow, 196 Miss. 159, 16 So.2d 372 (1944).

97. E.g., Shub v. Simpson, 340 U.S. 861 (1950).

98. MacDougall v. Green, 335 U.S. 281 (1948). But cf. Colegrove v. Green, 328 U.S. 549 (1946) (allegedly unconstitutional gerrymandering); Richardson v. McChesney, 218 U.S. 487 (1910) (same).

99. 312 Mass. 523, 45 N.E.2d 400 (1942). 
Such a holding presents dangers of its own, for to enable election officials to prevent all judicial review by delaying tactics is hardly calculated to assure fair dealing to all, regardless of political affiliation. A solution which has been utilized in election cases is advancement of the case to the top of the argument list, with every effort being made by the judges to decide it as quickly as possible before it becomes moot. ${ }^{100}$ An example of such a procedure, involving two separate court systems, is Ray v. Blair. ${ }^{101}$ On January 29, the plaintiff filed for a place on the primary ballot, and the final decision was announced by the United States Supreme Court on April 3, in ample time for the election in June. It took only one month to get a decision by the Alabama Supreme Court, ${ }^{102}$ and only thirty-four days for the highest court of the land to hear and decide the case.

A somewhat different method has been devised to assure that cases involving alleged disenfranchisement will remain vital controversies so that Supreme Court rulings may be obtained. Rather than seek equity relief, the potential voter attempts to cast his ballot and, following denial of the privilege, sues the election official for damages. ${ }^{103}$ Then, instead of a moot case, the Court is faced with a suit for damages caused by state action in violation of the Fourteenth Amendment. This procedure, although it does not attempt to secure to the plaintiff a vote in the particular election, has resulted in some historic decisions affirming to minority groups their access to the ballot. ${ }^{104}$

\section{The Public Interest Exception}

Many state courts have adopted an exception to the general rule of mootness by deciding moot cases when questions of great public interest are involved. Although this doctrine is not recognized by the federal courts, ${ }^{105}$ some of the state courts often cite certain language in the Trans-Missouri case ${ }^{106}$ as a basis for the proposition. The facts of that case indicate that

100. Such a procedure may be justified as an exercise of the judicial power to make rules of procedure and is warranted by the peculiar nature of these cases, which require prompt action by the courts to protect one of our most precious privileges.

101. Decision reported, 343 U.S. 154, opinion reported, 343 U.S. 214 (1952).

102. 257 Ala. 151, 57 So.2d 395 (1952).

103. The damages are set at an arbitrary figure high enough to meet all jurisdictional requirements regarding amount, usually $\$ 5000$ or $\$ 10,000$. See cases cited in note 104 infra.

104. Smith v. Allwright, 321 U.S. 649 (1944) ; Lane v. Wilson, 307 U.S. 268 (1939); Nixon v. Condon, 286 U.S. 73 (1932); Nixon v. Herndon, 273 U.S. 536 (1927).

105. Campbell Soup Co. v. Martin, 202 F.2d 398 (3d Cir. 1953). Contra: Boise City Irr. \& Land Co. v. Clark, 131 Fed 415, 418-19 (9th Cir. 1904) (alternative holding). See Diamond, supra note 82 , at 138 : "It seems significant ... that no case [in the Supreme Court] relies on public interest as the sole basis for exercising jurisdiction, and it is often expressed as a ground for retaining a jurisdiction which had properly attached at the commencement of the litigation."

106. United States v. Trans-Missouri Freight Ass'n, 166 U.S. 290, 309 (1897): "Here, however, there has been no extinguishment of the rights (whatever they are) of the public, the enforcement of which the Government has endeavored to procure by a judgment of a court under the provisions of the [Sherman] act ... above cited." 
the decision was grounded on the fear that the members of the defendant association would regroup and form another association which, while nominally a new entity, would in reality be merely a continuation of the challenged combination. ${ }^{107}$ As developed from the Trans-Missouri case, the continuing controversy doctrine permits decision of a case which is technically moot but represents only one phase of a still-existing dispute between the same parties. The public interest exception applies to moot questions which will arise again, but there is no requirement that the same parties will be involved in the subsequent controversy.

Importance of the Issues.-Although many of the opinions fail to delineate the basis for the exception, the principal requirement, discussed by most courts, is that the case involve issues important to the citizenry as a whole, as when the state acts as substantial trustee for the public in public utility regulation. ${ }^{108}$ A case affecting only a private associated group of individuals, no matter how large, will not qualify for the exception. ${ }^{109}$ It has been stated, very often by the United States Supreme Court, that the more important a case is, the more necessary is compliance with the traditional requirements for the exercise of the judicial power. ${ }^{110}$ This is true in regard to the first reason for the mootness doctrine-the requirement of adversity because of the danger of an unsound decision. Although it has been argued that a decision will remove much of the doubt and uncertainty which would result if such issues should remain undecided and will establish a basis for dealings by the persons or groups affected, ${ }^{111}$ this attempted justification only points out that people may be acting on an unsound decision. The second reason for mootness rules-economy of judicial endeavor-does not apply where the questions are very important to the whole public. Many of the decisions in moot cases have been relied upon as precedent; but even if they are not considered binding, the court can give enough indication of its thinking to bring about some concrete results, since presumably counselors and lower courts will refer to the opinion whenever the same or similar issues arise. Thus, it is not true that a court's judgment in a moot case will have no effect.

107. See text following note 82 supra.

108. See Willis v. Buchman, 240 Ala. $386,389,199$ So. 892,895 (1940). See also, Jones v. Crawford, 258 Ala. 278, 62 So.2d 221 (1952); Payne v. Jones, 193 Okla. 609, 146 P.2d 113 (1944) (collection of public revenue); Wisconsin Employment Relations Bd. v. Allis-Chalmers Workers' Union, 252 Wis. 436, 32 N.W.2d 190 (1948) (enforcement of labor relations statute). But cf. Wortex Mills, Inc. v. Textile Workers Union, $369 \mathrm{~Pa} .359,85$ A.2d 851 (1952).

109. North Dakota' Wheat Growers Ass'n v. Moore, 52 N.D. 904, 204 N.W. 834 (1925) (corporation with 15,000 members); cf. Campbell Soup Co. v. Martin, 202 F.2d 398 (3d Cir. 1953) (contracts between plaintiff and a large number of farmers). But cf. Maloney v. United Mine Workers, $308 \mathrm{~Pa} .251,162$ Atl. 225 (1932).

110. Frankfurter, J., in Youngstown Sheet \& Tube Co v. Sawyer, 343 U.S. 579, 594 (1952) (concurring opinion); Harris, The Judictal Power of tHe UNITED STATES 13 (1940): "Greater emphasis seems to be placed on the necessity of adverse parties with substantial interests in proceedings where the validity of the statute or order is questioned than in the other classes." See also, Cole v. Chief of Police of Fall River, 312 Mass. 523, 45 N.E.2d 400 (1942); State ex rel. Reilly v. Gress, 65 N.D. 184, 256 N.W. 721 (1934).

111. See text at note 11 and note 11 supra. 
Four principal categories of cases are considered sufficiently important to invoke the public interest exception. The first class consists of election matters. It is obviously of great importance to the electorate that the highest court of the jurisdiction definitely settle questions involving the propriety of holding an election, ${ }^{112}$ the right of candidates to have their names placed on the ballot, ${ }^{113}$ the right of citizens to vote, and the procedures of preparing, counting or certifying ballots. ${ }^{114}$ In Sartin $v$. Barlow ${ }^{110}$ the county district attorney alleged fraud and corruption in the vote count at a primary election and brought a mandamus action against the county clerk to enable the candidates to open the ballot boxes. Although the general election was to be held the day after the opinion was announced, the court ordered the clerk to make the ballot boxes available for inspection whenever the parties complied with the statutory procedure for making a demand. Delaying tactics employed by the county had prevented early decision, and the court feared that to allow such tactics to defeat review would enable wholesale evasion of the state's corrupt practices act.

This fear of administrative abuses is also an element in the second general category of cases, those in which the rulings of administrative agencies are challenged but become moot before reaching the court. An example of this category is the license cases considered previously. ${ }^{116}$ In some other situations, even though the plaintiff retains no residuum of interest as required by the license doctrine, review may be obtained under the public interest exception because the courts believe that the desirability of having a rule established for the agency's conduct in similar future situations outweighs the dangers inherent in deciding moot cases. ${ }^{117} \mathrm{~A}$ tacit

112. Pitt v. Belote, 108 Fla. 292, 146 So. 380 (1933); Dove v. Oglesby, 114 Okla. 144, 244 Pac. 798 (1926); Brown v. Leib, 267 Pa. 24, 110 At1. 463 (1920); cf. Maloney v. United Mine Workers, $308 \mathrm{~Pa}$. 251, 162 Att. 225 (1932).

113. Higgins v. Barnhill, 218 Ark. 466, 236 S.W.2d 1011 (1951); Carroll v. Schneider, 211 Ark. 538, 201 S.W.2d 221 (1947); Brown v. Leib, 267 Pa. 24, 110 Atl. 463 (1920). But cf. Lloyd v. Board of Supervisors, 111 A.2d 379 (Md. 1954). 114. Dotson v. Ritchie, 211 Ark. 789, 202 S.W.2d 603 (1947); Kensinger v. Schaal, 200 Ind. 275, 161 N.E. 262 (1928); Wattles ex rel. Johnson v. Upjohn, 211 Mich. 514, 179 N.W. 335 (1920) ; Sartin v. Barlow, 196 Miss. 159, 16 So.2d 372 (1944). But cf. J. B. Lyon Co. v. Morris, 261 N.Y. 497, 185 N.E. 711 (1933) (contract to print ballots).

115. 196 Miss. 159, 16 So.2d 372 (1944).

116. Text at notes $65-72$ supra.

117. Liquor board's authority to issue, suspend or revoke license: Van DeVegt v. Board of Comm'rs of Larimer County, 98 Colo. 161, 55 P.2d 703 (1936); Brown v. Baumer, $301 \mathrm{Ky} .315,191$ S.W.2d 235 (1945); Glenram Wine \& Liquor Corp. v. O’'Connell, 295 N.Y. 336, 67 N.E.2d 570 (1946); Perry v. Oregon Liquor Control Comm'n, 180 Ore. 495, 177 P.2d 406 (1947). But cf. People ex rel. Cairo Turf Club, Inc. v. Taylor, 2 Ill.2d 160, 116 N.E.2d 880 (1954) (no likelihood of repetition). Contra: Bartholomew v. Heil, $307 \mathrm{Ky} .686,211$ S.W.2d 673 (1947). Other cases are: St. Patrick's Church Corp. v. Daniels, 113 Conn. 132, 154 Atl. 343 (1931) (zoning variance); Florida ex rel. Railroad Comm'rs v. Southern Tel. \& Constr. Co., 65 Fla. 67, 61 So. 119 (1913) (authority of utility board to compel service by telephone company) ; People $\epsilon x$ rel. Wallace v. Iabrenz, 411 I1l. 618, 104 N.E.2d 769 (1952) (authority of juvenile court to order medical treatment of child over parents' religious objections); Rosenbluth v. Finkelstein, 300 N.Y. 402, 91 N.E.2d 581 (1950) (interpretation of Emergency Housing Act); State ex rel. Smith v. Smith, 197 Ore. 96, 252 P.2d 550 (1953) (authority of state tax comm'n to review local assessment 
example of this rule is found in the NLRB and FTC cases discussed above. ${ }^{118}$

A similar rationale is applied when the question relates to local government powers or procedures. ${ }^{119}$ The reasoning is particularly relevant where the issues could arise throughout the state, as when municipal authority under a state statute is questioned. ${ }^{\mathbf{1 2 0}}$ Although the public interest exception was not applied, a series of recent cases in Massachusetts will serve to illustrate the function of the exception in this field. ${ }^{121}$ The state statutory procedure for annual assessment of the value of utility property required that a certain administrative decision be made before December 1 of the calendar assessment year. In one of the cases, the administrative decision was not rendered until over a year later; the court dismissed the appeal from this decision as moot, saying that an appeal could never be completed in the required length of time and that no machinery was available to provide judicial review in this area. ${ }^{122}$ In successive cases, both the administrative and judicial processes were speeded up, until, in the most recent case, the court passed on the appeal

methods) ; McCanless v. Klein, 182 Tenn. 631, 188 S.W.2d 745 (1945) (liquor board's authority to require approval of new brand before sale); Peppers Refining Co. v. Corporation Comm'n, 198 Okla 451, 179 P.2d 899 (1947) (authority of corporation commission to reduce oil production quotas); Morad v. Wyoming Highway Dep't, 66 Wyo. 12, 203 P.2d 954 (1949) (interpretation of Drivers License Act).

An apparently unique provision is found in CAL. CODE CIv. Proc. \$1094.5(f) (1953), which provides that if a final administrative order is challenged "while the penalty imposed is in full force and effect the determination shall not be considered to have become moot" where the order expires or is complied with during the pendency of the appeal. See 6 OPS. ATT'Y Gen. of CALIF. 305 (1945) (license revoked for stated period, period expired).

118. See text at note 81 supra.

119. Wise v. First Nat. Bank, 49 Ariz. 146, 65 P.2d 1154 (1937) (city's duty to meet bond payments); Page v. Blunt, 126 Colo. 324, 248 P.2d 1074 (1952) (city's authority under liquor control act); Golden v. People ex rel. Baker, 101 Colo. 381, 74 P.2d 715 (1937) (same); Wattles ex rel. Johnson v. Upjohn, 211 Mich. 514, 179 N.W. 335 (1920) (validity of city's voting system); Cox v. City Council of Bristol, $144 \mathrm{Va}$. 286, 132 S.E. 187 (1926) (application of statute to city charter). But cf. Price v. Cohen, 109 A.2d 920 (Md. 1954) (authority of acting mayor under city charter to discharge appointed city official).

Cases not decided for other reasons: no likelihood of repetition: State ex rel. Ingle v. Folcomb, 199 Okla. 282, 185 P.2d 905 (1947) (appointment and tenure of school district officers) ; Keller v. Rewers, 189 Ind. 339, 127 N.E. 149 (1920) (city's authority to regulate saloons). Holding unclear: State ex rel. Anderson v. Sieg, 63 N.D. 724,249 N.W. 714 (1933) (authority of city council to hold recall election). Other remedy available: Kiker v. Wewoka, 205 Okla. 90, 235 P.2d 710 (1951) (city's authority to install parking meters).

120. Smith v. Ballas, 335 Ill. App. 418, 82 N.E.2d 181 (1948) (interpretation of liquor control act by city); State ex rel. Smith v. Smith, 197 Ore. 96, 252 P.2d 550 (1953) (authority of state tax comm'n to review local assessment methods); Pardee v. Schuylkill County, $276 \mathrm{~Pa} .246,120$ At1. 139 (1923) (authority of county tax comm'rs).

121. In chronological order, these cases are: Commissioner of Corps. and Taxation v. Assessors of Springfield, 329 Mass. 419, 108 N.E.2d 670 (1952) ; Commissioner of Corps. and Taxation v. Assessors of Springfield, 330 Mass. 433, 114 N.E.2d 550 (1953) ; Commissioner of Corps. and Taxation v. Assessors of Haverhill (two cases), 330 Mass. 553, 116 N.E.2d 151 (1953); State Tax Comm'n v. Assessors of Haverhill [and Springfield] (four cases), 118 N.E.2d 745 (Mass. 1954); State Tax Comm'n v. Assessors of Springfield, 122 N.E.2d 372 (Mass. 1954).

122. "If a remedy is needed, it lies beyond our province to provide one," State Tax Comm'n v. Assessors of Haverhill, 118 N.E.2d 745, 747 (Mass. 1954). 
on November 1 of the assessment year. ${ }^{123}$ Application of the public interest exception in the first case would have eliminated the need for a costly series of cases involving the same issues. ${ }^{124}$ Even more significant, the curative method of speeding up the legal machinery may not be available in every case of this nature.

The final major category of important questions is found in cases involving the constitutionality of a statute. Where many persons are affected by the statute, its validity is thought to be so important that a decision on it should be given without waiting until the issue is raised again. ${ }^{125}$ However, other courts have held that the doctrines restraining judicial power apply particularly to constitutional issues, and have refused to decide moot cases involving those issues. ${ }^{126}$ This view is strongly supported by the United States Supreme Court in the limitations on the judicial power expressed in its opinions. ${ }^{127}$

Other Factors.-In addition to the requirement that a matter of great importance be involved, two other factors are found in the factual situations of these cases which no doubt have an important influence on the court's willingness to invoke the public interest exception. Since there is little to be gained by deciding a moot case which is unique, ${ }^{128}$ the first factor is that the factual situation will recur frequently. ${ }^{129}$ However, this factor may be employed as an argument for dismissal. If the case is one which may arise soon again, the detrimental effects of postponing a decision

123. State Tax Comm'n v. Assessors of Springfield; 122 N.E.2d 372 (Mass. 1954). It is interesting to note that the decision of the administrative board in this case was reversed because of errors in procedure and the admission of evidence. No final determination of the assessment value of the property has yet been made by the court.

124. Cf. State ex rel. Smith v. Smith, 197 Ore. 96, 252 P.2d 550 (1953). The continuing controversy doctrine could probably have been applied also, since the parties were the same throughout the series of cases. See text following note 107 stipra.

125. Golden v. People ex rel. Baker, 101 Colo. 381, 74 P.2d 715 (1937); Pitt v. Belote, 108 Fla. 292, 146 So. 380 (1933); Letz Mfg. Co. v. Public Serv. Comm'n of Ind., 210 Ind. 467, 4 N.E.2d 194 (1936); Dove v. Oglesby, 114 Okla. 144, 244 Pac. 798 (1926); State ex rel. Stadter v. Newbry, 196 Ore. 331, 248 P.2d 840 (1952); State ex rel. Scandlyn v. Trotter, 153 Tenn. 30, 281 S.W. 925 (1925); Doering v. Swoboda, 214 Wis. 481, 253 N.W. 657 (1934); cf. State ex rel. Steere v. Franklin County Farm Bureau, 172 Kan. 179, 239 P.2d 570 (1951).

126. See cases cited in note 110 supra; Donato v. Board of Barber Examiners, 56 Cal. App.2d 916, 133 P.2d 490 (1943); State ex rel. Traub v. Brown, 39 Del. 187, 197 Atl. 478 (1938).

127. See, e.g., Brandeis, J., in Ashwander v. TVA, 297 U.S. 288, 341 (1936) (concurring opinion).

128. Because no likelihood of repetition was found, these cases were held to be moot: State ex rel. Ingle v. Holcomb, 199 Okla. 282, 185 P.2d 905 (1947); People

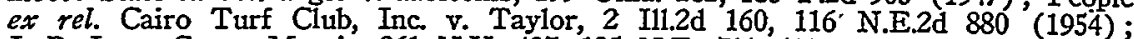
J. B. Lyon Co. v. Morris, 261 N.Y. 497, 185 N.E. 711 (1933); Keller v. Rewers, 189 Ind. 339, 127 N.E. 149 (1920). A decision on the merits of a unique moot case would be of academic interest only.

129. Almassy v. Los Angeles County Civ. Serv. Comm'n, 34 Cal.2d 387, 210 P.2d 503 (1949); Terry v. Civil Serv. Comm'n, 108 Cal. App.2d 861, 240 P.2d 691 (1952); Page v. Blunt, 126 Colo. 324, 248 P.2d 1074 (1952); Van DeVegt v. Board of Comm'rs of Larimer County, 98 Colo. 161, 55 P.2d 703 (1936); People ex rel. Wallace v. Labrenz, 411 Ill. 618, 104 N.E.2d 769 (1952) ; Payne v. Jones, 193 Okla. 609, 146 P.2d 113 (1944); Werner v. King, 310 Pa. 120, 164 Átl. 918 (1933); Doering v. Swoboda, 214 Wis. 481, 253 N.W. 657 (1934). 
will be alleviated within a short time, when the other cases come up on appeal. ${ }^{130}$ This argument gives rise to the conjunctive factor that the future cases will probably be moot also. ${ }^{131}$ The disputed matter may exist for only a short period of time, ${ }^{132} e . g$., a short term license; ${ }^{133}$ or the matter may have required prompt action, as in People ex rel. Wallace $v$. Labrenz, ${ }^{134}$ where an immediate transfusion was necessary to save a child's life and the lower court had authorized it despite the parents' religious objections. Such a case would always be moot, for if the transfusion were not given, the child would die, and if it were given, the propriety of ordering it done is then a dead issue.

In order to guarantee that the public interest exception will not destroy the principle of mootness, the three factors of effect on the public interest, future recurrence, and future mootness should be regarded as cumulative requirements. Even if all three are present, there still exists the danger that the lack of truly adversary argument will result in an unfortunate decision. Of course, a party may believe that he has a great interest in the disposition of the case, even though a court ordinarily would not recognize the interest as sufficient to render a decision. In these instances the party would have the incentive which is basic to the adversary system. ${ }^{135}$ Also, it is possible that the importance of the issues in the public interest cases may be a sufficient spur so that the party who does not have sufficient personal interest will still present proper argument or the court will arrive at the most desirable decision without proper argument: When a court decides a moot case under this exception, it should do so frankly and only after a conscientious attempt to make up for the probable lack of proper argument by diligent research and thorough analysis on its own part. ${ }^{138}$

130. See San Mateo County v. Southern Pac. R.R., 116 U.S. 138 (1885).

131. This element may also be argued both ways. It may be contended that if all cases which will arise will be moot, the chances are that the issues are so unimportant that the time of the appellate tribunal should not be taken up with such matters. However, this argument is met by the requirement that the case involve issues of great public importance.

132. Carroll v. Schneider, 211 Ark. 538, 201 S.W.2d 221 (1947); Sartin v. Barlow, 196 Miss. 159, 16 So.2d 372 (1944); Peppers Refining Co. v. Corporation Comm'n, 198 Okla. 451, 179 P.2d 899 (1947); Payne v. Jones, 193 Okla. 609, 146 P.2d 113 (1944); Doering v. Swoboda, 214 Wis. 481, 253 N.W. 657 (1934). This element was not found in Oregon State Grange v. McKay, 193 Ore. 627, 238 P.2d 778 (1951), rehearing denied, 193 Ore. 631, 239 P.2d 834 (1952), and the court properly refused, on rehearing, to apply the public interest exception. Cf. Kiker v. Wewoka, 205 Okkla. 90, 235 P.2d 710 (1951) (plaintiff could obtain decision on merits by pursuing remedy for damages).

133. E.g., Close v. Southern Md. Agric. Ass'n, 134 Md. 629, 108 Atl. 209 (1919) (13 day racing season); and other cases cited in note 69 supra.

134. 411 II1. 618, 104 N.E.2d 769 (1952).

135. A party may retain some interest without retaining enough to permit the decision of the case under the continuing controversy doctrine. An example of this may be found where the probability of repetition of the controversy depends entirely on one party. Even though the continuing controversy doctrine might not permit decision of the case, the public interest exception would so permit if the other elements were present.

136. An interesting sidelight is the practice of the federal courts in patent cases. Although "to hold a patent valid if it is not infringed is to decide a hypothetical case," Altvater v. Freeman, 319 U.S. 359, 363 (1943), lower federal courts have been advised to dispose of patent infringement suits on the grounds of invalidity rather than non-infringement where possible, Sinclair Co. v. Interchemical Corp., 
However, if the decision of a moot case involves extra work by the court, economy of judicial endeavor requires that such decisions be rendered only where the questions are so important that the interest in having them decided justifies the added work load on the judiciary.

The need for recognition of the interdependence of the three factors is heightened by the realization that the courts rely most strongly on the public right factor even though it is the one most vulnerable to criticism. The possibility of an unsound decision is most significant when the issues are important ones, and in such cases the courts should respect all the limitations on judicial power. The proper scope of the public interest exception then becomes more narrow, being limited to questions of great public importance which recur often but which probably will be moot upon reaching the appellate level. In many of these cases, the public's need for a judicial check on the executive and legislative branches of government will require that the court render a decision.

\section{Procedure}

Since, by hypothesis, the court's order cannot affect the rights of the parties to a moot case, many courts will simply dismiss the appeal whenever such a case is presented. ${ }^{137}$ This procedure is tantamount to affirming the judgment of the lower court, ${ }^{138}$ and leaves it in effect. However, in a significant number of cases, the plaintiff may be able to protect his rights through another action on a different legal theory. ${ }^{130}$ Such a situation was presented in United States $v$. Munsingrvear, ${ }^{140}$ in which the United States had sued to enjoin alleged violations of price regulations and also had sought treble damages. The damage action was held in abeyance pending decision on the injunction suit. The lower court held for the defendant in this suit, and before review could be obtained the regulations were re-

325 U.S. 327,330 (1945). If the lower court should rule on both questions as alternative holdings, the plaintiff must appeal on both, or he presents a moot case-he cannot agree on the issue of non-infringement and still attempt to remove the holding that his patent is invalid. Cover v. Schwartz, 133 F.2d 541 (2d Cir. 1942). But cf. Electrical Fittings Corp. v. Thomas \& Betts Co., 307 U.S. 241 (1939).

137. Love v. Griffith, 266 U.S. 32 (1924); Mills v. Green, 159 U.S. 651 (1895); Willis v. Buchman, 240 Ala. 386, 199 So. 892 (1940); Carroll v. Schneider, 211 Ark. 538, 201 S.W.2d 221 (1947); Dunn v. Dunn, 96 Ind. App. 620, 185 N.E. 334 (1933) ; Fox v. Holman, 95 Ind.'App. 598, 184 N.E. 194 (1933) ; State v. Sieg, 63 N.D. 724,249 N.W. 714 (1933); In re Kaeppler, 7 N.D. 307, 75 N.W. 253 (1898); Washington v. Cleland, 49 Ore. 12, 88 Pac. 305 (1907); Werner v. King, 310 Pa. 120, 164 Atl. 918 (1933) ; Maloney v. United Mine Workers, $308 \mathrm{~Pa}$. 251, 162 Atl. 225 (1932); Brown v. Lieb, $267 \mathrm{~Pa} .24,110$ At1. 463 (1920); Morad v. Wyoming Highway Dep't, 66 Wyo. 12, 203 P.2d 954 (1949).

138. Moot cases in which the judgment was affirmed: Swift \& Co. v. Hocking Valley Ry., 243 U.S. 281 (1917) ; Higgins v. Barnhill, 218 Ark. 466, 236 S.W.2d 1011 (1951) ; Piper v. Hawley, $179 \mathrm{Cal}$. 10, 175 Pac. 417 (1918); Van DeVegt v. Board of Comm'rs of Larimer County, 98 Colo. 161, 55 P.2d 703 (1936); Smith v. Ballas, 335 I1l. App. 418, 82 N.E.2d 181 (1948); Letz Mfg. Co. v. Public Serv. Comm'n, 210 Ind. 467, 4 N.E.2d 194 (1936); State v. Franklin County Farm Bureau, 172 Kan. 179, 239 P.2d 570 (1951) ; Feight v. State Real Estate Comm'n, 151 Neb. 867, 39 N.W.2d 823 (1949); State v. Trotter, 153 Tenn. 30, 281 S.W. 925 (1926).

139. See cases cited in notes $38-40$ supra.

140. 340 U.S. 36 (1950), discussed in Developments in the Law-Res Judicata, 65 HARV. L. Rev. 818, 847, 848 (1952). 
pealed and the appeal was dismissed as moot. ${ }^{141}$ Thereafter, the United States sought to press the action for damages. The Supreme Court held that the previous decision of the lower court was res judicata, pointing out that the United States had acquiesced in the dismissal by failing to object to that procedure. ${ }^{142}$ To avoid such a result, many courts have disposed of moot cases by vacating or reversing the judgment of the lower court and remanding the cause with directions to dismiss the bill or complaint, thus leaving no judgment on the record in the case. ${ }^{143}$ This procedure also prevents the lower court's judgment from standing as a precedent, which would appear to be especially desirable, for example, where a state wishes to reenact a statute declared unconstitutional by the lower court in a case moot on appeal. ${ }^{144}$ Occasionally, exceptional situations have arisen in which the courts have held that such procedure should not be followed, ${ }^{145}$ but it would appear more desirable to permit the court in the second case to exercise its discretion on the question of whether further litigation is desirable rather than have the question foreclosed by failure to invoke a procedural device, perhaps due to a party's oversight, in the case which was moot. Such an exercise of discretion by a court in the moot case would require some examination into the merits of the case and might lead to a weakening of the restrictions on the decision of moot cases. ${ }^{146}$

Generally, in determining its final order, a court need not and should not examine the issues of a moot case. In cases applying the public interest exception, the judgment of the court should not purport to order either party to do or refrain from doing any act, nor should it purport to affirm or reverse the judgment of the lower court which makes such an order. ${ }^{147}$ If a case has been made moot through the actions of one of the

141. Fleming v. Munsingwear, Inc., 162 F.2d 125 (8th Cir. 1947).

142. In St. Pierre v. United States, 319 U.S. 41 (1943), the Court indicated that the defendant's failure to apply for supersedeas could be regarded in the nature of an estoppel, preventing review of his conviction. See text at note 42 supra. Cf. Lloyd v. Board of Supervisors of Elections, 111 A.2d 379, 380, 382 (Md. Ct. of App. 1954). Since the state, as well as the defendant, has an interest in the effects of a conviction of a crime, see note 58 supra, the conviction should not be vacated unless it was erroneous.

143. This procedure is customary in the federal courts. See, e.g., United States v. Johnson, 319 U.S. 302 (1943) ; Alejandrino v. Quezon, 271 U.S. 528, 532 (1926) ; Brownlow v. Schwartz, 261 U.S. 216 (1923); Acheson v. Droesse, 197 F.2d 574 (D.C. Cir. 1952) and cases cited therein.

State courts: e.g., People v. Redlich, 402 Ill. 270, 80 N.E.2d 736 (1949); Adirondack League Club v. Board of Black River Regulating Dist., 301 N.Y. 219, 93 N.E.2d 647 (1950); Brace v. Steele County, 77 N.D. 276, 42 N.W.2d 672 (1950); San Antonio v. Brown, 50 S.W.2d 344 (Tex. Civ. App. 1932). See also cases cited in note 147 infra.

Ct. 1938).

144. Contra: State ex rel. Traub v. Brown, 39 Del. 187, 197 At1. 478 (Sup.

145. United States v. Munsingwear, Inc., 340 U.S. 36, $39-40$ (1950); Cover v. Schwartz, 133 F.2d 541, 546-47, (2d Cir. 1942). But cf. Acheson v. Droesse, 197 F.2d 574 (D.C. Cir. 1952).

146. See Hart \& Wechsler, The Federai Courts and the Federat System 121-22 (1953).

147. Some courts applying the public interest exception follow the practice of the cases cited note 143 supra, although, since there has been a fully considered decision by the court on the merits, there is less reason to do so. Pitt v. Belote, 108 Fla. 292, 146 So. 380 (1933); Rosenbluth v. Finkelstein, 300 N.Y. 402, 91 N.E.2d 581 (1950). 
parties, a court can utilize this fact as a basis for awarding costs to the other party, ${ }^{148}$ but even here there is no necessity for passing on the issues in the case.

\section{CONCLUSION}

The best procedure for alleviating the problems raised by moot cases is to accelerate the legal process whenever a case is presented which will probably become moot because of normal docket delay. This has been done with questions of public importance, principally election cases, in the United States Supreme Court. ${ }^{149}$ Such procedure was also employed in the Massachusetts assessment cases discussed previously. ${ }^{150}$ It would seem that on a showing that the case will become moot, advancement should be granted almost as a matter of course; otherwise effective review will be denied in these cases. ${ }^{151}$ The difficulty in relying on this procedure exclusively is that in some instances ${ }^{152}$ it is not possible to move quickly enough through the appellate process to secure a decision before the case becomes moot.

Where possible, the plaintiff can secure appellate review by seeking damages instead of, or in addition to, injunctive or mandatory relief. This is especially desirable where the plaintiff's principal object is to seek a ruling to govern future conduct, as in the disenfranchisement cases; ${ }^{153}$ however, an action for money damages often cannot be combined with an equity suit, and frequently will not achieve the plaintiff's purpose.

Appeals of criminal convictions present a special problem and should be heard except where there is genuine acquiescence. The serious extralegal as well as the legal consequences of convictions may far outweigh the damage to the defendant which was caused by satisfaction of the sentence. The decision of these cases should be made by the judiciary, rather than the executive through pardons, because the judicial branch of government is best suited to deal with the problems involved in determining the validity of criminal convictions.

The preferable rule generally is that moot cases should not be decided. Where overriding considerations of policy exist, the courts should attempt to set forth the rule of law which they deem controlling, primarily as a guide for the future conduct of law enforcement bodies and law abiding citizens. Such decisions may be justified under either the continuing controversy or public interest lines of cases. An example may serve to illustrate the value of and the differences between the doctrines. Each year, the

148. Heitmuller v. Stokes, 256 U.S. 359 (1921).

149. See notes 100,101 supra.

150. See text at notes 121-24 supra.

151. Compare Ray v. Blair, 343 U.S. 154, 214 (1952), with Shub v. Simpson, 340 U.S. 861, 881 (1950). See also, Youngstown Sheet \& Tube Co. v. Sawyer, 343 U.S. 579 (1952) (executive order promulgated April 8, Supreme Court decision rendered June 2). See also Lloyd v, Board of Supervisors of Elections, 111 A.2d 379, 382 (Md. Ct. of App. 1954).

152. See text following note 131 supra.

153. See text following note 102 supra. 
Philadelphia City Council has passed a rent control ordinance. In several cases, these ordinances have been declared unconstitutional by local county courts. ${ }^{154}$ Before appellate review of the first of these decisions could be obtained, however, the ordinance had expired and the case was dismissed as moot. ${ }^{155}$ To obtain review under the continuing controversy doctrine, it would be necessary for the plaintiff to show that the ordinance has been reenacted or that another ordinance which is substantially the same has been passed or is about to pass and that this ordinance will affect the particular person before the court in the moot case. To qualify under a strict public interest exception, it would be necessary to show that the question is one of great public importance, ${ }^{156}$ that it is one which will recur frequently, and that it is likely that any case in the future involving the same question will become moot before final review can be obtained. In this instance, not only would it probably be easier to meet the requirements of the continuing controversy doctrine, but that doctrine would, as in most cases, assure that the purposes of the mootness doctrine would most nearly be served. Under this doctrine, as compared to the public interest exception, the issues are more narrow and it is more likely that the particular plaintiff involved will still have a substantial interest in the outcome of the litigation.

For a court to make an exception to so fundamental a jurisdictional rule as the one precluding the decision of moot cases, certain safeguards should be erected to prevent the dangers against which the rule was designed to guard. Even though sound precedent may arise from a court's decision in a moot case involving questions of great public importance, it should always be borne in mind that legislative or executive action can also accomplish this purpose in many instances, ${ }^{157}$ and that it is to keep clear the lines of demarcation between the branches of govenment that the various restrictions on the judicial power were developed and should be maintained. When such a moot case is decided the courts should take every precaution to insure that adverse and complete argument, or its equivalent, is presented.

154. Warren et al. v. Philadelphia, No. 6301, Philadelphia County C.P. No. 5. June Term, 1953, decided Jan. 29, 1954; Warren et al. v. Philadelphia, No. 7354, Philadelphia County C.P. No. 5, March Term 1954, decided Dec. 30, 1954; Warren et al. v. Philadelphia, No. 6327, Philadelphia County C.P. No. 5, Dec. Term, 1954, decided March 2, 1955.

155. Warren et al. v. Philadelphia, No. 279, Jan. Term, 1954, Pa. Sup. Ct., Oct. 6,1954 . The appeals in the later cases are now pending in the Pennsylvania Supreme Court. E.g., Warren et al. v. Philadelphia No. 201, Jan. Term, 1955, Pa. Sup. Ct.

156. Since the persons opposing the ordinance do not represent the public as a whole, but merely a portion of the property owners in the City of Philadelphia, and since the question affects only one municipality in the state, it is doubtful whether the test of public importance is met in this case. See notes 109, 119, 120 supra. Pennsylvania cases applying the public interest exception in this area are Maloney v. United Mine Workers, $308 \mathrm{~Pa}$. 251, 162 Atl. 225 (1935); Pardee v. Schuylkill County, $276 \mathrm{~Pa} .246,120$ Atl. 139 (1923).

157. See Lloyd v. Board of Supervisors of Elections, 111 A.2d 379 (Md. Ct. of App. 1954), where the court refused to decide a moot election case under the public interest doctrine because the challenged administrative ruling had existed for six years and the state legislature had not seen fit to change it. 